\title{
CHEMOTHERAPY IN MALIGNANT DISEASE The Present Position
}

\author{
A. E. R. Buckle, M.B., B.S., F.R.C.S., M.R.C.O.G. \\ Senior Registrar in Obstetrics and Gynacology, King's College Hospital, London, S.E.5, \\ and the Woolwich Group of Hospitals
}

IN the treatment of cancer all efforts are directed towards the total elimination of the malignant tissue by means of surgery, radiotherapy or a combination of both. There will be many occasions when this ideal will be impossible of achievement and, whilst surgery may be required for the relief of symptoms at the primary site, it will be of no avail in the treatment of widely scattered metastases. In turn, radiotherapy may be of limited value, either on account of radio-resistance of the tumour cells or the impracticability of treating widely spread deposits.

Despite the earlier diagnosis and increased scope and safety of operation, there has been but little rise in the overall survival from all forms and all stages of malignant disease. Consequently attempts have been directed towards treatment by chemical means and over the last i 5 years various cytotoxic drugs have been introduced into cancer therapeutics. Although no chemical compound has been found which is capable of curing cancer, many substances are available whose action is to induce remissions for varying lengths of time. Such drugs may be divided into the following groups (Goodman and Gilman, 1955):

\section{Cytotoxic Drugs Acting by Virtue of Chemical Properties}

These drugs, which include the antimetabolites and the alkylating agents, are discussed in greater detail below. They have no selectivity of action, the vulnerability of the cells being related to their mitotic activity.

\section{Drugs Exerting Their Effect by Altering the Environ- ment of the Cancer Cells}

These drugs induce remissions in tumours which show hormone dependence, examples being the use of androgens in the treatment of carcinoma of the breast and of æstrogens in the treatment of carcinoma of the prostate and breast. In acute leukæmia in childhood, where the cells escape from the control normally exercised by the adrenal steroids, the use of induced hypercorticism leads to a remission, of variable duration, in some
30 to $50 \%$ of cases (Burchenal, Murphy and Tan, 1956).

Substances Acting by Virtue of Physical Properties (Radioactive Isotopes)

These substances, exerting their effect by means of ionizing radiations, are not chemotherapeutic drugs, but, in so far as they are capable of inducing remissions in certain cases of cancer, are mentioned for completeness. Their action is not selective, but because of the distribution of a particular element within the body high local activity may be achieved, as is the case after the uptake of radioactive iodine by thyroid tissue.

Discussion in this article concerns those drugsึ के which fall into the first-mentioned group, namely cytotoxic drugs, which act by virtue of chemicap properties. Knowledge of the composition and bio-synthesis of the nucleic acids is helpful in understanding their mode of action and is now briefly mentioned.

The nucleic acids, complex structures containing purine and pyrimidine bases, differ chiefly in the sugar present in the molecule; one contains d-ribose and is referred to as ribonucleic acid, RNA, and the other contains 2-deoxyribose and is referred to as deoxyribonucleic acid, DNA. The nucleic acids are polynucleotides, each nucleotide being composed of phosphoric acid, pentose and either a purine base (adenine or guanine) or a pyrimidine base (uracil, thymine or cytosine). Both types of nucleic acid contain adenine, guanine and cytosine, but uracil is found only in RNA and thymine and 5-methyl cytosine only in DNA.

RNA is found mainly in the cytoplasm, with smaller amounts in the cell nuclei; DNA is confined to the nuclei, where it exists in combination with various nucleoproteins.

In view of the importance of nucleic acid metabolism to the life of the cell and the relation between DNA and cell multiplication, much effort has been directed towards the inhibition of cell division, especially of neoplastic cells, by the use of substances which, on theoretical grounds, might be expected to inhibit nucleic acid bio- 
synthesis. Such substances might act indirectly by inhibiting purine or pyrimidine nucleotide biosynthesis, or nucleic acid biosynthesis might be inhibited by the use of purine or pyrimidine analogues (Davidson, 1960).

Drugs from both these groups have been, or are being, used in cancer therapeutics, but it must again be emphasized that there is no specificity of action and that nucleic acid biosynthesis of all cells is affected, the use of such drugs being necessarily associated with systemic toxic reactions. Nevertheless, as the degree of damage inflicted is related to the mitotic activity of the cells, more pronounced effects may be expected to occur in neoplastic tissue.

Biochemical research may eventually reveal differences in the structure of the nucleic acids of tumour cells or of the enzyme systems responsible for their synthesis which distinguish them from those of normal cells or their enzyme systems. It may then be possible to employ agents which exert a specific inhibitory effect on tumour cells.

\section{The Antimetabolites}

\section{Folic Acid Antagonists}

Folic acid is converted by two different enzyme systems, firstly to dihydrofolic acid and secondly to tetrahydrofolic acid, the latter being essential in two formylation stages which introduce one-carbon units in purine and pyrimidine biosynthesis (Davidson, 1960). The folic acid antagonists may affect the incorporation of precursors into nucleic acids, such action not being confined to any particular group of cells, so that the use of the former must necessarily lead to systemic toxic effects, chief amongst which are buccal and intestinal ulceration, diarrhœa, melæna and bone marrow depression (the latter leading to anæmia, thrombocytopenia and leucopenia).

The two more important drugs in this group are aminopterin (4-amino pteroyl glutamic acid) and methotrexate (4-amino, N Io-methyl pteroyl glutamic acid). Both have found their main use in the treatment of acute leukæmia in childhood, remissions occurring in from 30 to $70 \%$ of cases (Burchenal et al., 1956).

It has also been found that the folic acid antagonists interfere with normal embryonic development (Hertz, 1948; Hertz and Tullner, 1949) and aminopterin can induce fœtal death in utero (Thiersch, 1952). The use of both drugs is contraindicated during pregnancy, for major abnormalities have been found following administration during the first trimester (Sokal and Lessman, 1960).

Methotrexate is currently in use in the treatment of chorioncarcinoma, either alone or in combination with other cytotoxic drugs $(\mathrm{Li}, \mathrm{Hertz}$ and Spencer,
1956; Li, Hertz and Bergenstal, 1958; Hertz, Bergenstal, Lipsett, Price and Hilbish, 1958; Li, Whitmore, Golbey and Grabstald, 1960).

\section{Glutamine Analogues}

The diazo-amino acids azaserine (o-diazoacetyl1-serine ) and DON (6-diazo-5-oxo-norleucine) were discovered during the search for anti-tumour antibiotics. They are structural analogues of glutamine, react competitively with the latter and block its utilization in purine synthesis (Davidson, 1960). Both inhibit growth and induce abnormalities in embryonal development (Dagg, Karnafsky, Lacon and Roddy, 1956; Murphy and Karnafsky, 1956).

Although remissions have followed the use of these two substances in the treatment of malignant disease, the systemic toxic effects encountered were severe and neither drug is in current use.

\section{Purine Analogues}

Unnatural analogues of the purine base, such as 6-mercaptopurine and 8-azaguanine, have been used in cancer therapeutics. Their action is to block some stage in purine biosynthesis, 6-mercaptopurine blocking the conversion of inosinic acid to adenosine monophosphate and 8-azaguanine inhibiting the biosynthesis of guanine monophos phate (Davidson, 1960).

6-mercaptopurine has been used particularly in the treatment of acute leukæmia in childhood (Burchenal et al., 1956), remission being obtained in some $50 \%$ of cases. Although the chief effect is exerted on the bone marrow, gastro-intestinal disturbance may follow the use of the drug and hepatic damage has been reported (Clark, Hsia and Huntsman, 1960). It is of interest that crosstolerance does not appear to develop between this drug and aminopterin when both are employed in the treatment of acute leukæmia.

6-mercaptopurine has also been used in combination with methotrexate in the treatment of chorioncarcinoma (Li et al., 1958; Buckle, r959, 196r).

\section{Pyrimidine Analogues}

The use of the fluorinated pyrimidines, 5fluorouracil and 5-fluoroorotic acid (Heidelberger, Chaudhuri, Danneberg, Mooren, Griesbach, Duschinsky, Schnitzer, Pleven and Scheiner, 1957), in cancer chemotherapy was suggested by the profound biological effects occasionally obtained when - F was substituted for - $\mathrm{H}$ in several classes of compound together with the effectiveness, albeit limited, of nucleic acid analogues in human cancer. 5 -fluorouracil is the more active, being converted to its ribonucleotide and then to its deoxyribo- 
nucleotide, the latter inhibiting the formation of thymidine monophosphate.

The use of the drug (Curreri, Ansfield, McIver, Waisman and Heidelberger, 1958) has led to a transient regression in a variety of malignant conditions, but the therapeutic ratio is low, regression only occurring when the drug is given to toxic levels, so limiting its usefulness. A recent paper (Hurley, Ellison, Riesch and Schulte, I960) reports satisfactory results in the treatment of advanced carcinoma of the breast using 5 -fluorouracil in combination with other cytotoxic drugs.

\section{Compounds of Uncertain Metabolic Activity}

Puromycin, an antibiotic isolated from a species of actinomycete (Streptomyces albo-niger), was shown to exert an inhibitory action against certain tumours in addition to an anti-bacterial effect. Structurally the compound is 6-dimethylamino( $3^{\prime}-$ p-methoxy-L-phenylalaninamino- $3^{-}$deoxyD-ribosyl) purine and, although the mode of action is uncertain, it is reasonable to assume that it acts as a purine analogue. Administered to patients with incurable disease, puromycin led to temporary improvement in about $25 \%$ of instances, but generally there was little effect on the downhill course. Side-effects encountered during therapy were vomiting and diarrhœa; bone marrow depression was not marked (Wright, Dolgopol, Logan, Prigot and Wright, 1955).

Actinomycin, a peptide-containing antibiotic substance, was originally isolated by Waksman and Woodruff (1940) from Streptomyces antibioticus. Similar substances are produced by a large number of streptomyces and some I I have been identified. They are polypeptides linked to a chromophoric quinonoid moiety and the structural variations are limited to substitutions amongst the amino-acids of the peptide chains (Woodruff and Waksman, 1960). Of these substances, only Actinomycin D is relatively pure.

The mode of action is not known, but it is suggested that Actinomycin D interferes with the pantothenate-dependent reactions concerned with the biosynthesis and/or utilization of amino-acids, possibly by interference with the activity of coenzyme A (Foley, 1955). In vitro studies with HeLa cells have shown that Actinomycin D inhibits RNA and protein synthesis and that a specific effect appears to be exerted on the nucleolus (Goldstein, Slotnick and Journey, 1960).

Given by intravenous injection, Actinomycin D has led to regression in cases of Wilm's tumour in children and some effect has been obtained in cases of rhabdomyosarcoma and neuroblastoma (Tan, Dargeon and Burchenal, 1959; Shaw, Moore, Mueller, Frei and Walkin, 1960). Temporary remissions in adults with a variety of neo- plastic conditions have been reported (Watne, Badillo, Koike, Kondo and Moore, I960), but variations in response were noted in patients with similar lesions, improvement was transient and the result was not related to the dose of Actinomycin D employed.

Potentiation of the predicted response to radiotherapy has been reported to follow the use of the drug (Tan et al., 1959).

Toxic effects encountered during treatment include nausea, vomiting, diarrhœa, alopecia, marrow depression and local thrombophlebitis at the site of intravenous injection. Increased pigmentation at the site of irradiation has been noted in patients receiving simultaneous Actinomycin $\mathrm{D}$ and deep $\mathrm{X}$-ray therapy.

Vincaleukoblastine is an alkaloid containing indole and dihydro-indole moieties and was originally isolated from the herb Vinca rosea Linn. (Noble, Beer and Cutts, 1958). Preliminary studies suggest that the anti-metabolic activity may result from interference with glutamic acid participation in the citric acid and ornithine cycles (Johnson, Wright, Svoboda and Vlantis, r960). Clinical trials are in progress with this drug, the use of which has led to a favourable response in Hodgkin's disease, acute and chronic leukæmias, chorioncarcinoma and occasionally in other malig nant tumours (Hodes, Rohn and Bond, 1960 Hertz, Lipsett and Moy, 1960).

\section{The Alkylating Agents}

The mode of action of these substances has been described by McFarland (1958). Removal of the hydroxyl group from ethyl alcohol leaves the alkyl group $\mathrm{CH}_{3} \cdot \mathrm{CH}_{2}$; this and similar groups do not exist as separate molecules, but are referred to as alkyl groups and their combination with other substances is referred to as alkylation. In the case of nitrogen mustard, the sequence of reaction is:

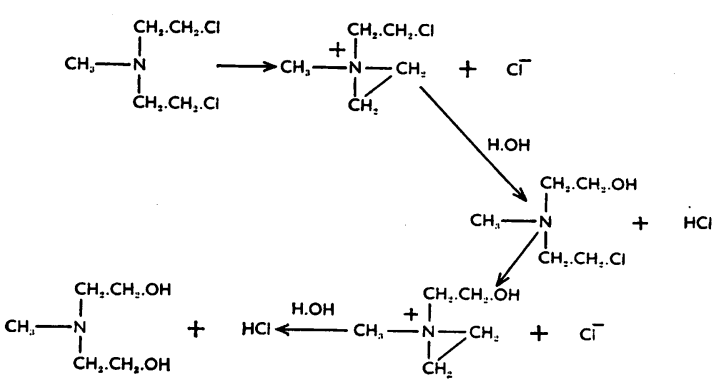

In other words, in neutral or alkaline aqueous solution intramolecular transformation occurs with the release of chloride ion and the formation of a cyclic ethyleneimonium compound which is highly 
active. This in turn reacts, leading to the formation of an inactive tertiary amine, and it may be noted that the alkylating agents may be mono-, bi- or polyfunctional, depending on the number of active groups available.

The reactive centres of the alkylating agents behave as positively-charged carbonium ions, which have a particular affinity for electron-rich groups in biological systems, such as organic and inorganic anions, amino groups and sulphydryl groups. The most common and important of these reactions appears to involve the primary phosphate group in DNA and, when such reaction results from the use of a polyfunctional agent, cross-linkage occurs with the disruption of the normally straight-chain polymers. In other words, the molecule of the alkylating agent, with its two or three reactive centres, forms an abnormal bridge between different polymers of DNA. Such changes in chromosomal material produce marked effects on cell division (McFarland, 1958 ).

The changes produced by the alkylating agents resemble those produced by $\mathrm{X}$-rays. In the case of the latter, energy is deposited at random in all cell constituents, subsequent chemical changes being found at points where little harm is done as well as at vulnerable points. Chemical change is produced after X-ray exposure in a few vital macro-molecules, leading to an initial minor disturbance. The cell metabolism then develops this primary injury to produce metabolic changes, such as reduced DNA synthesis, which in turn leads to anatomical damage.

In the case of the alkylating agents, inactivation of DNA also occurs, with a similar progression from macro-molecular damage to obvious anatomical change, but the effects are due in this instance to a biochemical, as distinct from a biophysical, change.

The important point to be appreciated is that DNA consists of two polynucleotide chains held together by regular hydrogen bondage. A reduction in molecular weight requires two breaks, close together, in each chain and it has been estimated that a dose of radiation of the order of $1,000 \mathrm{r}$ leads to a break in the chain in about $3 \%$ of all DNA molecules present. Such breakage of the nucleotide chain is likely to prevent a DNA molecule from exerting its normal biological function and the reaction is responsible for the initiation of the processes which result in the observed radiation lesions in cells (Alexander and Stacey, 1958).

\section{Nitrogen Mustards}

The activity of these substances (nitrogen analogues of sulphur mustard) is due, as outlined above, to the di-( $\beta$-chloroethyl) grouping. The following drugs are, or have been, used in cancer therapeutics:

Mustine $\left[\mathrm{HN}_{2}\right.$ : methyl bis ( $\beta$-chloroethyl) amine]. Although absorption from the intestine occurs, the drug is normally given, well diluted, by the intravenous route. Systemic toxicity is manifested by early nausea and vomiting, followed some seven days later by depression of hæmatopoiesis, the latter reaching a maximum at two to three weeks and then regressing. The drug is rapidly transformed and there is little excretion in the active form.

Mustine is used in the treatment of Hodgkin's disease and lymphosarcoma. It has also been employed in chronic myeloid leukæmia and some success has followed its palliative use in carcinoma of the bronchus and breast (Karnofsky, 1958).

Mannitol Mustard [1,6 bis( $\beta$-chloroethylamino) I,6 deoxy-D-mannitol hydrochloride]. The modification of the alkylating group in mannitol mustard was introduced on the supposition that the cell membrane could be more readily passed by substances which take part in cell metabolism, in this case a sugar.

Given intravenously, the indications and toxic effects are as stated for mustine (Sellei and Eckhardt, 1958; Papac, Petrakis, Amini and Wood, 1960).

Endoxan [N,N-bis-( $\beta$-chloroethyl)-N-o-propylene phosphoric acid ester amide]. This substance appears to act by the splitting off of the propylene phosphamide group from the $\beta$-chloroethyl group by enzyme action (phosphatases and phosphamidases) in the tumours, the active group being liberated locally.

The drug is given intravenously or orally and there appears to be less gastro-intestinal disturbance than with mustine. Alopecia may follow the use of the drug, the remaining toxic effects and clinical indications being as for mustine (Papac et al., 1960).

Chloroquine and Quinacrine Mustards. The mustard derivatives of the anti-malarials were introduced after it had been found, during investigation of the latter, that there was selective concentration in certain parenchymatous organs and that, within the cell, the drugs localized and accumulated in the nucleus. Chloroquine mustard produced some effect in Hodgkin's disease, leukæmias and neuroblastomas, but the use of the drug was limited by toxic effects on the central nervous system. Quinacrine mustard was used in the treatment of myelomatosis and chronic lymphatic leukæmia, but led to severe marrow depression (Jones, Jonsson, Browning, Lessner, Price and Sen, 1958). Neither drug is currently in use.

Sulphur Mustard: Hemi-sulphur Mustard. Both 
drugs, given intravenously, have the same indications and side-effects as mustine and no advantages over the latter (Petrakis, Wood, Mettier, Costantini and Farber, 1958).

\section{Ethyleneimine Derivatives}

Triethylene Melamine [TEM: 2,4,6-tris(ethyleneimino)-s-triazine]. The cytotoxic action of this substance is similar to that of the mustards. It is less irritant to the gastro-intestinal tract and is active orally, especially if transformation in the acid medium of the stomach is prevented by the simultaneous administration of sodium bicarbonate. It has a therapeutic range of the same order as chlorambucil (vide infra) and as the effects of the latter are more predictable its use is preferred (Kravitz, Diamond and Craver, I95I ; Rundles, Coonrad and Willard, 1958).

TEPA: Thio-TEPA. Two further drugs in this group are triethylene phosphoramide and its thio-derivative. The latter has been used extensively in a variety of malignant conditions, sometimes being used in conjunction with radical surgery and sometimes in purely palliative fashion. It has found use in adenocarcinoma of the ovary, carcinoma of the breast, melanotic sarcoma and lymphomas. It may be given intravenously or by direct injection into tumour masses or serous cavities. The toxic effects include vomiting, headache and marrow depression, the latter being delayed as much as 30 days after completion of treatment, and is the major factor limiting dosage (Ultmann, Hyman, Crandall, Naujoks and Gellhorn, 1957; Wright, Golomb and Gumport, 1958; Englander and Sarangi, 1960).

\section{Myleran [1,4-dimethanesulphonyloxybutane]}

This substance, a sulphonic acid ester, has an action similar to that of the nitrogen mustards. Although gonadal damage may follow its use, leading to permanent amenorrhœa in the premenopausal female, its cytotoxic action is almost entirely confined to the bone marrow and the drug has been used with success in the treatment of chronic granulocytic leukæmia (Galton, 1953; Galton, Till and Wiltshaw, 1958). The drug is administered orally and continued until optimal response is obtained. Though tolerance may develop, the drug is sometimes effective in patients who no longer respond to radiation. Myleran has been suggested in the treatment of some cases of myelofibrosis with myeloid metaplasia (Dameshek, Granville and Rubio, 1958).

\section{Chlorambucil [ $p$-(di-2-chloroethylamino)-phenyl butyric acid]}

Of a series of water-soluble aromatic nitrogen mustards synthesized, chlorambucil has under- gone extensive clinical trial. Its effects resemble those of the other alkylating agents, but it is active orally, there is less variation in dose response and less systemic toxicity.

The diseases responding best to chlorambucil are those characterized by abnormal lymphocytic proliferation; a satisfactory response is seen in cases of lymphosarcoma and chronic lymphatic leukæmia, with a less satisfactory response in cases of Hodgkin's disease (Israels, Galton, Till and Wiltshaw, 1958; Ultmann, Hyman and Gellhorn, 1958; Miller, Diamond and Craver, 1959).

Amino-acids Carrying the Nitrogen Mustard Group

Melphalan (phenyl alanine nitrogen mustard; p-di-2-chloroethylamino-L-phenylalanine) and the racemic form, sarcolysine, are currently in trial use. Both produce only transient response in Hodgkin's disease and the effect is less marked than that produced by chlorambucil (Papac, Galton, Till and Wiltshaw, 1958). Sarcolysine has been reported to produce marked remission in cases of seminoma and Ewing's tumour (Blokhin, Larionov, Perevodchikova, Chebotareva and Merkulova, 1958).

\section{Uracil Mustard [5-bis(2-chloroethyl)aminouracil]}

This drug, in which the mustard radical is $\overrightarrow{\mathscr{E}}$ attached to the pyrimidine base uracil, has beep introduced recently into cancer therapeutics. The drug, which is effective orally, is of value in chronie lymphocytic and myeloid leukæmia, lymphosarcoma, mycosis fungoides and polycythæmia vera (Shanbrom, Miller, Haar and Opfell, 1960). Side-effects appear to be less marked than with other mustard analogues and the dosage required is small.

The drugs mentioned above have normally been given by the routes indicated. The reactivity time of the alkylating agents is brief, being of the order of a few minutes, and the systemic toxic effects, rather than the clinical response, may be the factor which determines the dosage used.

In an attempt to select that drug which will exert maximum effect tissue cultures of the cells of the tumour in question have been made, the effect on their growth of available cytotoxic drugs noted, the drug finally selected being the one producing the most marked cytotoxic effect. Correlation between in vitro and in vivo results have been obtained (Wright, Cobb, Gumport, Golomb and Sasadi, I957).

-Methods of delivering a higher concentration of a given cytotoxic agent to a tumour mass than is possible by conventional methods are being utilized in an attempt to enhance the effect and at the same time reduce the systemic toxicity. These methods include direct injection of the tumour 
Table 1.-The More Important Cytotoxic Drugs and their Main Clinical Indications

\begin{tabular}{|c|c|c|c|}
\hline Drug & & Main Clinical Indication & Dosage* \\
\hline Aminopterin .. & . & $\begin{array}{l}\text { Acute leukæmia, especially in } \\
\text { children }\end{array}$ & $\begin{array}{l}\text { Children: } 0.25-0.5 \mathrm{mg} \text {. orally daily for } 3 \text { weeks or more, } \\
\text { until remission occurs. } \\
\text { Adults: } 5^{-10} \mathrm{mg} .3^{-6} \text { times weekly, until remission occurs. }\end{array}$ \\
\hline Methotrexate .. & .. & $\begin{array}{l}\text { Acute leukæmia, especially in } \\
\text { children } \\
\text { Chorioncarcinoma }\end{array}$ & $\begin{array}{l}\text { Children: } 1.25-5.0 \mathrm{mg} \text {. orally daily for } 2 \text { weeks or more. } \\
\text { Adults: } 20-25 \mathrm{mg} \text {. orally daily for } 5 \text { days. Repeat as } \\
\text { required. } \\
\text { Dosage in chorioncarcinoma-see quoted articles. }\end{array}$ \\
\hline 6-mercaptopurine & . & $\begin{array}{l}\text { Acute leukæmia, especially in } \\
\text { children }\end{array}$ & 2.5 mg. per kg. body weight orally daily for $3^{-6}$ weeks. \\
\hline 5-fluorouracil . : & $\therefore$ & $\begin{array}{l}\text { Various, solid tumours, especi- } \\
\text { ally colon and breast }\end{array}$ & $\begin{array}{l}\text { I } 5 \text { mg. per kg. daily, intravenously, at intervals of } 4-6 \\
\text { weeks. Repeat as required. }\end{array}$ \\
\hline Vincaleukoblastine & .. & $\begin{array}{l}\text { Hodgkin's disease } \\
\text { Acute and chronic leukæmia }\end{array}$ & $\begin{array}{l}0.15 \mathrm{mg} \text {. per } \mathrm{kg} \text {. body weight, } \mathrm{i}-\mathrm{v} \text {, weekly for } 4 \text { weeks. } \\
\text { Maintain by further dose every } \mathrm{I}-2 \text { weeks; discontinue } \\
\text { if white cell count falls below } 4,000 \text { per cu.mm. }\end{array}$ \\
\hline Actinomycin D & . & $\begin{array}{l}\text { Wilm's tumour } \\
\text { Rhabdomyosarcoma } \\
\text { Neuroblastoma }\end{array}$ & $\begin{array}{l}\text { Total dose of } 70 \mu \mathrm{g} \text {. per } \mathrm{kg} \text {. body weight, intravenously, } \\
\text { over 5-10 days. }\end{array}$ \\
\hline Mustine & $\cdots$ & $\begin{array}{l}\text { Hodgkin's disease } \\
\text { Lymphosarcoma } \\
\text { Mycosis fungoides } \\
\text { Palliative (breast: bronchus) }\end{array}$ & $\begin{array}{l}\text { Total dose of } 0.4 \mathrm{mg} \text {. per kg. body weight, intravenously, } \\
\text { given over } 4 \text { days. }\end{array}$ \\
\hline Thio-TEPA $\ldots$ & . & $\begin{array}{l}\text { Variety of malignant growths, } \\
\text { especially breast and ovary }\end{array}$ & $\begin{array}{l}0.2 \text { mg. per } \mathrm{kg} \text {. body weight, intravenously, daily for } \\
5 \text { days. }\end{array}$ \\
\hline Myleran & .. & Chronic myeloid leukæmia & $\begin{array}{l}0.06 \mathrm{mg} . \text { per kg. body weight orally, daily, until optimum } \\
\text { benefit obtained. }\end{array}$ \\
\hline Chlorambucil & . & $\begin{array}{l}\text { Lymphosarcoma } \\
\text { Chronic lymphatic leukæmia } \\
\text { Hodgkin's disease }\end{array}$ & $\begin{array}{l}0.1-0.2 \mathrm{mg} \text {. per } \mathrm{kg} \text {. body weight orally, daily for } 4^{-6} \\
\text { weeks. }\end{array}$ \\
\hline Uracil-mustard & $\cdots$ & $\begin{array}{l}\text { Hodgkin's disease } \\
\text { Chronic lymphatic leukæmia } \\
\text { Mycosis fungoides } \\
\text { Chronic myeloid leukæmia }\end{array}$ & $\begin{array}{l}\text { I-2 mg. daily orally until clinical improvement occurs or } \\
\text { leucopenia develops. Then I mg. daily for } 3 \text { weeks out } \\
\text { of } 4 \text { weeks. }\end{array}$ \\
\hline
\end{tabular}

* These doses are average ones. In all instances dosage must be adjusted to the individual patient, depending on response and systemic toxicity.

mass, direct injection into the artery supplying an affected area and the use of regional perfusion, utilizing an extracorporeal circuit. The latter method is particularly suitable for the treatment of pelvic cancer, cancer in one limb or cancer of the head and neck. The compounds used in such treatment have been chosen empirically and have included nitrogen mustard, thio-TEPA, melphalan and Actinomycin D (Creech, Krementz, Ryan and Winblad, 1958; Creech, Ryan and Krementz, I959; Creech, Krementz, Ryan, Reemtsma, Elliot and Winblad, r959; Austen, Monaco, Richardson, Baker, Shaw and Raker, 1959).

Alternatively, high systemic concentration may be achieved, with lessened risk of marrow aplasia, if preliminary marrow aspiration with the re- injection of the stored marrow after completion of the course of chemotherapy is performed. By this method a vastly higher dosage of cytotoxic agent can be employed (Westbury, Humble, Newton, Skinner and Pegg, 1959).

Various combinations of cytotoxic drugs are employed, either simultaneously or sequentially, in an attempt to enhance the effect on neoplastic tissue ( $\mathrm{Li}$ et al., 1958, 1960). Trials are also in progress in which pre- and post-operative administration of cytotoxic drugs is combined with surgery in the management of malignant disease.

These methods of treatment are of recent introduction and time must elapse before assessment can be made as to their ultimate role in the treatment of cancer. In particular great care must be 
taken to relate the survival period in patients who have received cytotoxic drugs to that obtained with other methods of therapy, as well as the natural history of the untreated disease.

In conclusion, the drugs at present available are of great value both in treatment and in the elucidation of metabolic pathways (Nyhan, 1959). The findings of differences in structure of the nucleic acids (or the enzyme systems responsible for theief synthesis) between normal and malignant cells may provide the key to cancer therapeutics, for if might then be possible to select substances whiclo would act on the cancer cell alone. The magnitudê and complexity of the problem has been outlined. recently (Todd, 1959); until such time, bio $\stackrel{5}{\rightarrow}$ chemical research will continue to provide drug worthy of clinical application.

\section{REFERENCES}

Alexander, P., and Stacey, K. A. (1958): Comparison of the Changes Produced by Ionising Radiations and by the Alkylating Agents, Ann. N.Y. Acad. Sci., 68, 1225.

Austen, W. G., Monaco, A. P., Richardson, G. S., Baker, W. H., Shaw, R. S., and Raker, J. W. (1959): Treatment of Malignant Pelvic Tumours by Extracorporeal Perfusion with Chemotherapeutic Agents, New Engl. $\%_{\vec{H}}$ Med., 261, 1037.

Blokhin, N., Larionov, L., Perevodchikova, N., Chebotareva, L., and Merkulova, N. (1958): Clinical Experience with Sarcolysine in Neoplastic Disease, Ann. N.Y. Acad. Sci., 68, i 128.

BuckLE, A. E. R. (1959): Methotrexate in Treatment of Metastasizing Chorioncarcinoma, Brit. Med. Y., ii, 1210.

- (196I): Further Experience with Methotrexate in Chorioncarcinoma, Ibid., i, 173.

Burchenal, J. H., Murphy, M. L., and TAN, C. T. C. (1956): Treatment of Acute Leukæmia, Pediatrics, 18, 643.

Ciba Foundation Symposium (1958): 'Amino-acids and Peptides with Antimetabolic Activity'. London: J. \& A Churchill.

Clark, P. A., Hsia, Y. E., and Huntsman, R. G. (I960): Toxic Complications of Treatment with 6-mercaptopurin $\xi^{\omega}$ Brit. med. F., i, 393.

Creech, O. J., Jr., Krementz, E. T., Ryan, R. F., and Winblad, J. N. (1958): Chemotherapy of Cancer: Regiona Perfusion Utilising Extra-corporeal Circuit, Ann. Surg., 148, 616.

,$--1-(1959)$ : Treatment of Melanoma by Isolation Perfusion Technique, f. Amer. med. Ass., 169, 339. $\vec{c}$ , - - Reemtsma, K., Elliott, J. L., and Winblad, J. N. (I959) Perfusion Treatment of Patients wits Cancer, Ibid., I7r, 2069.

Curreri, A. R., Ansfield, F. J., McIver, F. A., Waisman, H. A., and Heidelberger, C. A. (1958): Clinical Studies-

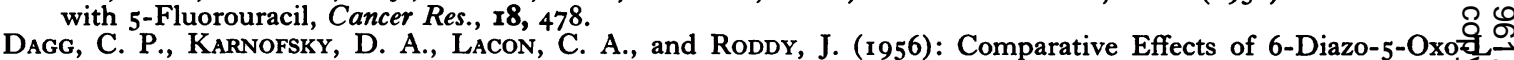
Norleucine and o-Diazoacetyl-L-Serine on the Chick Embryo, Proc. Amer. Ass. Cancer Res., 2, ror.

DamesheK, W., Granville, N. B., and Rubio, F., Jr. (1958): Therapy of the Myeloproliferative disorders with Myleris Ann. N.Y. Acad. Sci., 68, roor.

Davidson, J. N. (1960): 'The Biochemistry of the Nucleic Acids', 4th ed. London: Methuen.

Ellison, R. R., Karnofsky, D. A., Sternberg, S. S., Murphy, M. L., and Burchenal, J. H. (1954): Clinical Trial of o-Diazoacetyl-L-Serine (Azaserine) in Neoplastic Disease, Cancer (Philad.), 7, 801.

ENGLANDER, O., and SARANGI, A. (1960): Effect of Thio-TEPA on Advanced Malignant Ovarian Tumours, Brit. $\%$ Cancer, 14, 28.

Foley, G. E. (1956): Preliminary Observations on the Mechanism of Action of Actinomycin D in Microbiologica? Systems, 'Antibiotics Annual', p. 432. New York: Medical Encyclopedia Inc.

Galton, D. A. G. (1953): Myleran in Chronic Myeloid Leukæmia, Lancet, i, 208.

-, Israels, L., Nabarro, J. D. N., and Till, M. (1955): Clinical Trials of p-(di-2-Chloroethylamino) Pheny? Butyric Acid (CB 1348) in Malignant Lymphomas, Brit. med. F., ii, 1172.

- TILL, M., and WiltSHAW, E. (1958): Busulphan (1.4-Dimethanesulphonyloxybutane; Myleran); Summary of Chinical Results, Ann. N.Y. Acad. Sci., 68, 967.

GoldSTEIN, M. N., Slotnik, T. J., and Journey, L. J. (1960): In vitro Studies with HeLa Cell Lines Sensitive and Resistant to Actinomycin D, Ibid., 89, 474.

Goodman, L. S., and Gilman, A. (1955): 'The Pharmacological Basis of Therapeutics', 2nd ed. New York: Thêं MacMillan Company.

Heidelberger, C. A., Chaudhuri, N. K., Danneberg, P., Mooren, D., Griesbach, L., Duschinsky, R., Schnitzero R. J., Pleven, E., and Scheiner, J. (1957): Fluorinated Pyrimidines, a New Class of Tumour-inhibitory Com? pounds, Nature (Lond.), 179, 663.

HerTz, R. (1948): Dietary Impairment of Estrogen Response in the Immature Monkey, Proc. Soc. exp. Biol. (N.Y.) 厓. 67, 113 .

, and Tullner, W. W. (1949): Quantitative Interference with Estrogen-induced Tissue Growth by Folic Aci

Antagonists, Endocrinology, 44, 278. carcinoma and Related Trophoblastic Tumors in Women, F. Amer. med. Ass., 168, 845.

, LIPSETT, M. B., and Moy, R. H. (1960): Effect of Vincaleukoblastine on Metastatic Choriocarcinoma and Relate Trophoblastic Tumors in Women, Cancer Res., $20,1050$.

Hodes, M. E., Rohn, R. J., and BoND, W. H. (1960): Vincaleukoblastine: (I) Preliminary Clinical Studies, Ibid 20, 1041 .

Hurley, J. D., Ellison, E. H., Riesch, J., and Schulte, W. (1960): Chemotherapy of Solid Carcinoma, f. Amer.? med. Ass., 174, 1696.

Israels, L. G., Galton, D. A. G., Till, M., and Wiltshaw, E. (1958): Clinical Evaluation of CB 1348 in Malignan Lymphoma and Related Diseases, Ann. Y.N. Acad. Sci., 68, 915. 
Johnson, I. S., Wright, H. F., Svoboda, G. H., and Vlantis, J. (1960): Antitumor Principles Derived from Vinca Rosea Linn: (I) Vincaleukoblastine and Leurosine, Cancer Res., 20, I0I6.

Jones, R., Jr., Jonsson, U., Browning, M., Lessner, H., Price, C. C., and Sen, A. K. (1958): Initial Clinical Trial of the Nitrogen Mustard Analogues of Chloroquine and Quinacrine; a Preliminary Report, Ann. N.Y. Acad. Sci., 68, 1133 .

K? RNOFSKY, D. A. (1958): Summary of Results Obtained with Nitrogen Mustard in the Treatment of Neoplastic Disease, Ibid., 68, 899.

Kravitz, S. C., Diamond, H. D., and Craver, L. F. (1952): The Clinical Use of Triethylene Melamine, Blood, 7, 729.

LI, M. C., HeRTZ, R., and SPENCER, D. B. (1956): Effect of Methotrexate Upon Choriocarcinoma and Chorioadenoma, Proc. Soc. exp. Biol. (N.Y.), 93, 361.

- , and Bergenstal, D. M. (1958): Therapy of Choriocarcinoma and Related Trophoblastic Tumors with Folic Acid and Purine Antagonists, New Engl. Y. Med., 259, 66.

- Whitmore, W. F., Golbey, R., and Grabstald, H. (1960): Effects of Combined Drug Therapy on Metastatic Cancer of the Testis, $\mathcal{F}$. Amer. med. Ass., 174, 1291.

MCFarLand, K. (1958): Alkylating Agents: a Brief Review, U.S. armed Forces med. J., 9, 795.

Magill, G. B., MYers, W. P. L., Reilly, H. C., Putnam, R. C., Magill, J. W., SYKes, M. P., Escher, G. C., KARNOFSKY, D. A., and BURChENAL, J. H. (1957): Pharmacological and Initial Therapeutic Observations on 6-Diazo-5-Oxo-I-Norleucine (DON) in Human Neoplastic Disease, Cancer (Philad.), 10, I 138.

Miller, D. G., Diamond, H. D., and Craver, L. F. (I959): The Clinical Use of Chlorambucil: a Critical Study, New Engl. $\mathcal{F}$. Med., 26r, 525.

MURPhy, M. L., and KARNoFSKy, D. A. (1956): Effect of Azaserine and other Growth-inhibiting Agents on Fetal Development in the Rat, Cancer (Philad.), 9, 995.

Noble, R. L., BeER, C. T., and CUTTS, J. H. (r958): Role of Chance Observations in Chemotherapy: Vinca Rosea, Ann. N.Y. Acad. Sci., 76, 882.

Nyhan, W. L. (1959): Approaches to the Chemical Therapy of Tumors, $\mathcal{F}$. Pediat., 55, 337.

Papac, R., Galton, D. A. G., Till, M., and Wiltshaw, E. (1958): Preliminary Clinical Trial of p-2 Chloroethylamino-L-Phenylalanine (CB 3025: Melphalen), Ann. N.Y. Acad. Sci., 68, ir26.

-, Petrakis, N. L., Amini, F., and Wood, D. (1960): Clinical Evaluation of Two Alkylating Agents, f. Amer. med. Ass., 172, 1387.

Petrakis, N. L., Wood, D. A., Mettier, S. R., Costantini, A. V., and Farber, S. M. (1958): Preliminary Clinical Evaluation of 1,2 -bis (b-Chloroethylthio) ethane (SM-I) in Patients with Advanced Lymphomas and Neoplastic Diseases, Ann. N.Y. Acad. Sci., 68, I1 51 .

Rundles, R. W., Coonrad, E. V., and Willard, N. L. (1958): Summary of Results Obtained with T.E.M., Ibid., 68, 926.

SelleI, C., and EckHaRdT, S. (1958): Clinical Observations with r.6-bis (-Chloroethylamino)-1.6-Deoxy-D-MannitoB Dihydrochloride (BCM) in Malignant Disease, Ibid., 68, 1164 .

Shanbrom, E., Miller, S., HaAR, H., and OpfEll, R. (1960): Therapeutic Spectrum of Uracil-Mustard, a New Orąa Antitumor Drug, $\mathcal{F}$. Amer. med. Ass., 174, 1702.

Shaw, R. K., Moore, E. W., Murller, P. S., Frei, M., and Watkin, D. M. (1960): The Effect of Actinomycin D on Childhood Neoplasms, Amer. F. Dis. Child., 99, 628.

Sokal, J. E., and Lessman, E. M. (1960): Effect of Cancer Chemotherapeutic Agents on the Human Fetus, f. Amer. med. Ass., 172, 1765.

Tan, C. T. C., Dargeon, H. W., and Burchenal, J. H. (1959): The Effect of Actinomycin D on Cancer in Childhood, Pediatrics, 24, 544.

Thiersch, J. B. (I952): Therapeutic Abortions with Folic Acid Antagonist, 4-Amino Pteroyl Glutamic Acid (4-Amino P.G.A.) Administered by the Oral Route, Amer. F. Obstet. Gynec., 63, 1298.

TodD, SiR A. (1959): Nucleic Acids and Their Role in Future Chemotherapy of Tumours and Virus Diseases, Brit. med. $\mathcal{Y}$., ii, 5 I 7.

Ultmann, J. E., Hyman, G. A., Crandall, C., Naujoks, H., and Gellhorn, A. (1957): Triethylene Thiophosphoramide (Thio-TEPA) in the Treatment of Neoplastic Disease, Cancer (Philad.), ro, 902.

,-- , and Gellmorn, A. (1958) Chlorambucil and Triethylene Thiophosphoramide in the Treatment of Malignant Disease, Ann. N.Y. Acad. Sci., 68, 1007.

Waksman, S. A., and WoodrufF, H. B. (1940): Bacteriostatic and Bactericidal Substances Produced by a Soil Actinomyces, Proc. Soc. exp. Biol. (N.Y.), 45, 609.

Watne, A. L., Badillo, J., Koike, A., Kondo, T., and Moore, G. E. (1960): Clinical Studies of Actinomycin D, Ann. N.Y. Acad. Sci., 89, 445.

Westbury, G., Humble, J. G., Newton, K. A., Skinner, M. E. G., and PegG, D. E. (1959): Disseminated Malignant Melanoma: Response to Treatment by Massive Dosage of a Cytotoxic Agent Combined with Autogenous Marrow Replacement, Lancet, i, 968.

WoodRufF, H. B., and WakSman, S. A. (1960): Historical Background in The Actinomycins and Their Importance in the Treatment of Tumours in Animals and Man, Ann. N.Y. Acad. Sci., 89, 287.

Wright, J. C., Dolgopol, V. B., Logan, M., Prigot, A., and Wright, L. T. (1955): Clinical Evaluation of Puromycin in Human Neoplastic Disease, Arch. intern. Med., 96, 61.

, CoBb, J. P., Gumport, S. L., Golomb, S. L., and SaSADI, D. (1957): Relation Between Tissue Culture and Clinical Response to Chemotherapeutic Agents and Human Cancer, New Engl. F. Med., 257, 1207.

, Golomb, F. M., and Gumport, S. L. (1958): Summary of Results with Triethylene Thiophosphoramide, Ann. N.Y. Acad. Sci., 68, 937. 